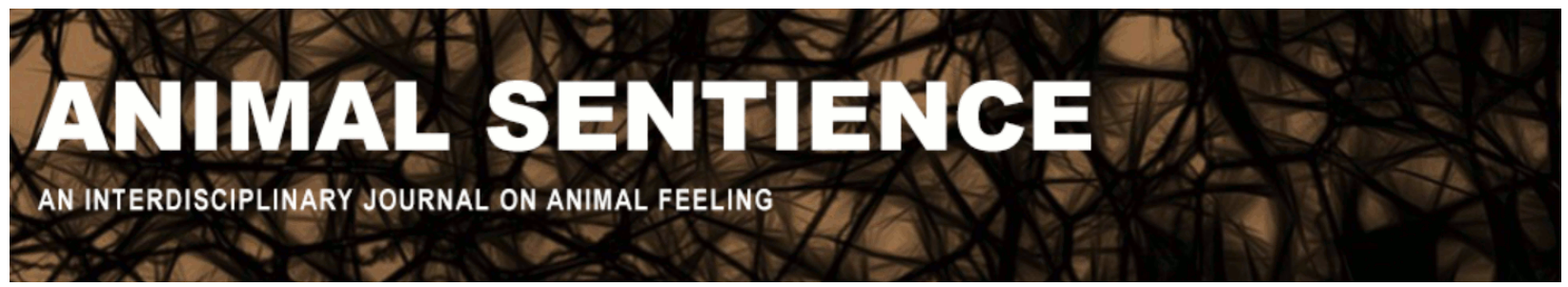

Malpede, Karen (2016) Hermes in the Anthropocene: A dogologue. Animal Sentience 5(12)

DOI: $10.51291 / 2377-7478.1074$

Date of submission: $2015-12-27$

Date of acceptance: 2015-12-29

(c)

This article has appeared in the journal Animal

Sentience, a peer-reviewed journal on animal

cognition and feeling. It has been made open access,

free for all, by WellBeing International and deposited

in the WBI Studies Repository. For more information,

please contact

wbisr-info@wellbeingintl.org.

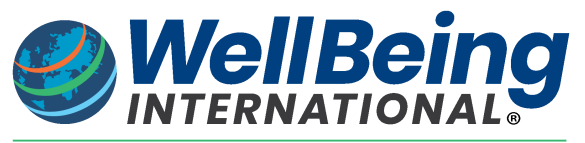

SOLUTIONS FOR PEOPLE, ANIMALS AND ENVIRONMENT 


\title{
Hermes in the Anthropocene: A dogologue
}

\author{
Commentary on Broom on Animal Welfare
}

\author{
Karen Malpede \\ Communications and Theatre Arts \\ John Jay College of Criminal Justice
}

\begin{abstract}
In this dogologue, a writer and the dog who sits near her desk as she works speak. The dog is concerned about the fate of the world in the hands of humans. His urgent questions send the writer into the world of her own memories when she was a child alone with a horse in nature.
\end{abstract}

\begin{abstract}
Karen Malpede kmalpede@ijay.cuny.edu, ecofeminist playwright, is author of 17 fulllength produced plays, most recently, "Extreme Whether," about climate change. She is cofounder of Theater Three Collaborative and adjunct professor of Theater and

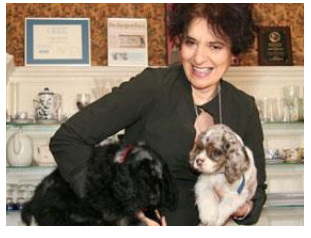
Environmental Studies at John Jay College of Criminal Justice, City University of New York. Hermes is a ten-year-old merle, though mainly black, cocker spaniel. He has always spoken and his human companion, a writer, has always voiced his words and answered him back.

http://www.jjay.cuny.edu/faculty/karen-malpede
\end{abstract}

I was in conversation with my dog, Hermes. He lay on the floor next to my desk.

"Kawhren," Herm said. He has trouble with "r" sounds and speaks with a slight accent that must be cocker spaniel. "Why cannot people, undewhrstrand?"

"I don't know, Herm," I said. I find I often answer his questions this way.

He returned to gently licking his left paw, then asked: "Do you rwhemembwer the days of yowre?"

"Herm, whatever are you talking about?"

"The days of yoehre, Kawhren. (pause) Befowre ..."

He turned to grooming his right paw. Hermes has huge feet of which he is quite proud. Finished grooming himself, he stretched and did upward and downward dog on the rug, wagging his tale in recognition of his perfect form. Then he looked up at me.

"When you was young." He said.

"Oh, yes, I do remember, Hermes," I said. "I used to ride my bicycle down streets lined with old elms whose branches touched forming a canopy above my head. That was before Dutch Elm disease."

"Why would anyone hurt a twree?" Hermes asked, aghast.

"You pee on trees," I reminded him.

"Big twrees, only, Kawhren, nevewhr pee on little twrees." Hermes lay down; his two back legs splayed out, head on his paws, brown eyes wide open, contemplating what I'd said. 
He had started me thinking, too. I used to ride horses into the deep woods. I used to head out alone, bareback, no one else but me and my horse, sometimes at night, under the moon, but most often in the middle of the heat of the Midwestern summer's day. From the cool woods, we'd come into a small round meadow, shaded and sheltered by trees. I'd slide down his warm flesh, lean my cheek against his neck. l'd lie down, my horse grazing at my side, my eyes ground-level, I would stare into the miniature world. Graceful long-necked insects with delicately-etched transparent wings balanced on spindly legs atop slender blades of grass bent by their weight and chattered back and forth. Busy ants carried burdens twice their size. Worms surfaced and dove. Spiders wove translucent webs. Bees darted and drank. Linnet wings, the words pop into my head, beautiful like so many of nature's names on the tongue. Staring into the miniature world of meadow grasses and bugs eye-level to the child belly pressed to the earth is how the world of fairies, hence fairy tales, began.

"Kawhren," Hermes said, urgent, coming, now, to the point of his discourse, "you neverh thought when you were young that people would hurwt the wowrold!"

"Never, Hermes." That wasn't true. I was a child in the worst days of the Cold War; we thought nuclear weapons would destroy the world. My world in the secret meadow with the piebald grazing at my side was going to be blown apart. Now, we watch the ice melt and wait.... But from these thoughts, I could protect my dog.

"I neverh would huwrt," Hermes said.

"Well, you eat raw beef and chicken, Herm."

"And pizza crwusts," he said.

"From the street, ick."

"No one is pewrfect, Kawhren. We is each one of us comprowmized. But that does not mean," he continued emphatically, standing up, "that we should not twry. In evwry way we know." He rested his chin on my leg. "I twry by being a good dog."

"This is true, Hermes," I said, rubbing his head, "you are the best dog I know." Unlike his sister, Cleis, whom I dearly love, Hermes is universally kind, friendly and biddable.

"Cleis does not talk," Herm said, reading my mind.

"That is true, Herm," I replied, although Hermes speaks to me inside my head and I must verbalize for him, Cleis, no matter how hard I listen remains resolutely silent. I cannot hear the sound of her voice. I can, however, read the expressions on her face. Cleis is below size for a spaniel; she is white, brown and gray and has sharp blue eyes. She is extremely bright but she gets herself into plenty of trouble. Both Hermes and I are completely devoted to her. Often we find ourselves protecting her from large dogs she has growled at. When Cleis wants to be a brat, as in the park, she closes her ears to the sound of my voice, nose to the ground, and runs in circles, free and feral. I call after her, sometimes, I foolishly chase her. I beg her with biscuits. When she is tired, she sits.

I had a riding teacher who used to say, "They tell me the horses are the dumb animals, but I wonder," referring to those of us struggling to communicate with the thousand pounds of flesh between our legs without being summarily tossed off.

"Kawhrewn," said Herm, "why are people so dumb?" He was angry, now.

For added emphasis he barked. Cleis barked, too. Then as often happens, their barking accelerated until they were howling together, wildly, with abandon. 
Once the cacophony stopped, Hermes pulled himself very straight; front legs planted, back legs extended, his head up. He spoke with gravitas, "Ourhr beautiful worwold. Ourhr only one."

\section{References}

Broom, D.M. (2014). Sentience and animal welfare. Wallingford: CABI. 